\title{
Ekman and Eddy Exchange of Freshwater and Oxygen across the Labrador Shelf Break $\mathcal{O}$
}

\author{
TARA HOWATT ${ }^{\mathrm{a}}$ AND JAIME B. PALTER ${ }^{\mathrm{b}}$ \\ Department of Atmospheric and Oceanic Sciences, McGill University, Montreal, Quebec, Canada \\ JOHN BRIAN ROBIN MATTHEWS ${ }^{\mathrm{c}}$ AND BRAD DEYOUNG \\ Department of Physics and Physical Oceanography, Memorial University of Newfoundland, St. John's, \\ Newfoundland and Labrador, Canada \\ RALF BACHMAYER ${ }^{\mathrm{d}}$ AND BRIAN CLAUS ${ }^{\mathrm{e}}$ \\ Faculty of Engineering and Applied Science, Memorial University of Newfoundland, St. John's, \\ Newfoundland and Labrador, Canada
}

(Manuscript received 21 July 2017, in final form 1 December 2017)

\begin{abstract}
Transport of freshwater from the Labrador Shelf into the interior Labrador Sea has the potential to impact deep convection via its influence on the salinity of surface waters. To examine this transport, the authors deployed two underwater gliders on a mission to traverse the continental shelf break multiple times between 5 July and 22 August 2014, the period when Arctic meltwater has historically peaked in transport down the Labrador Shelf. The field campaign yielded a unique dataset of temperature, salinity, and oxygen across the shelf break to a depth of $1000 \mathrm{~m}$ at unprecedented spatial resolution. Two mechanisms of cross-shelf transport were examined: Ekman transport and transport due to mesoscale eddies. Ekman transport is quantified using satellite wind stress and near-surface hydrographic properties, and eddy-induced transport is scaled using a parameterized eddy diffusivity and thickness gradients of layers of uniform potential density, as well as the tracer gradients along those isopycnals. Both the Ekman and eddy terms transport high-oxygen and low-salinity water from the shelf to the Labrador Sea during the field campaign. The influence of the eddy-driven oxygen flux from the shelf to the Labrador Sea on oxygen budgets depends strongly on the size of the region over which this eddy flux converges. The deduced offshore transport of freshwater $(4 \pm 6 \mathrm{mSv}$; $1 \mathrm{mSv}=10^{3} \mathrm{~m}^{3} \mathrm{~s}^{-1}$ ) from both Ekman and eddy mechanisms, which is likely at a seasonal maximum during this summertime survey, represents about 3\% of the annual-mean freshwater flowing through Hudson and Davis Straits but may be an important component of the total freshwater budget of the interior Labrador Sea.
\end{abstract}

\footnotetext{
Supplemental information related to this paper is available at the Journals Online website: https://doi.org/10.1175/JPO-D-170148.s1.

${ }^{\mathrm{a}}$ Current affiliation: Department of Earth, Ocean and Atmospheric Sciences, The University of British Columbia, Vancouver, British Columbia, Canada.

${ }^{\mathrm{b}}$ Current affiliation: Graduate School of Oceanography, University of Rhode Island, Narragansett, Rhode Island.

${ }^{\mathrm{c}}$ Current affiliation: Université Paris Saclay, Saint-Aubin, France.

${ }^{\mathrm{d}}$ Current affiliation: Center for Marine Environmental Sciences, University of Bremen, Bremen, Germany.

${ }^{\mathrm{e}}$ Current affiliation: Department of Applied Ocean Physics and Engineering, Woods Hole Oceanographic Institution, Woods Hole, Massachusetts.
}

Corresponding author: Tara Howatt, thowatt@eoas.ubc.ca

\section{Introduction}

The Labrador Sea in the North Atlantic and the Weddell Sea in the Southern Ocean both factor prominently in setting the properties of a large volume of the global ocean, given that deep and bottom waters are formed in these seas (Mantyla and Reid 1983). The formation mechanisms of these water masses, however, are very different in the two basins. Bottom water is mainly formed on the Antarctic continental shelf of the Weddell Sea and entrains Weddell Deep Water as it spills turbulently downslope (Orsi et al. 1999). In contrast, Labrador Sea Water (LSW) is formed by open-ocean deep convection in the interior Labrador Sea, with a contribution from 
convection in the Deep Western Boundary Current (Pickart et al. 2002; Palter et al. 2008).

Thompson et al. (2014) recently proposed the following steady-state mass budget for the Weddell Shelf in which on-shelf flow driven by winds and eddies is balanced by offshore transport in the bottom boundary layer:

$$
\mathscr{C}_{\mathrm{Ek}}+\mathscr{M}_{e}+\mathscr{C}_{\text {bottom }}=0,
$$

where $\mathscr{C}_{\mathrm{Ek}}, \mathscr{\mathscr { C }}_{e}$, and $\mathscr{C}_{\text {bottom }}$ are surface Ekman, mesoscale eddy, and bottom boundary mass transports, respectively. To assess the Ekman and eddy terms, Thompson et al. (2014) used wind stress observed by satellite and eddy-driven transport estimated from sections collected by gliders. Gliders are autonomous underwater vehicles that can sample the upper water column at a high spatial resolution. These observations revealed that both Ekman and eddy transport brought water onto the Weddell Sea continental shelf, with the potential to influence bottom water formation in the winter. During Thompson et al.'s (2014) austral summer survey, the eddies supplied about half as much onshore transport as the Ekman term. Offshore transport in the bottom boundary layer was assumed to close the budget.

Here, we use a similar set of satellite and glider data to estimate the fluxes of mass, freshwater, and oxygen across the Labrador Current, the gateway between the Labrador Shelf and Sea. Within and just offshore of this current, LSW is formed through open-ocean convection each winter (Pickart et al. 2002; Palter et al. 2008). The Labrador Current is part of the cyclonic boundary current system of the subpolar North Atlantic, which flows southward along the Labrador continental shelf (Loder et al. 1998). Primary sources of Labrador Shelf and Labrador Current water include 1) the east-west Greenland Current system (Lazier and Wright 1993); 2) waters flowing through Davis Strait (Loder et al. 1998; Cuny et al. 2005; Curry et al. 2011) and Hudson Strait (Loder et al. 1998; Straneo and Saucier 2008), including a mixture of meltwater that originated from the west Greenland outlet glaciers (Gillard et al. 2016) and a cold intermediate layer originating from Lancaster Sound or formed locally on the Labrador Shelf (Petrie et al. 1992; Drinkwater 1996; Cuny et al. 2005); and 3) LSW that has been entrained into the Labrador Current (Palter et al. 2008).

The Labrador Current separates into two branches: the main, outer branch that runs along the shelf break and an inner branch that splits from the main branch near Hamilton Bank and rejoins on the Newfoundland Shelf, just north of Flemish Pass (Colbourne et al. 1997;
Lazier and Wright 1993; Han et al. 2008). Fratantoni and McCartney (2010) compiled 100 years of hydrographic data to construct a detailed description of the mean and seasonal evolution of freshwater pathways along the Labrador Shelf. They showed that a salinity minimum occurs at Hamilton Bank in July and propagates along the shelf at about $1800 \mathrm{~km} \mathrm{month}^{-1}$, reaching the Grand Banks in October. Thus, our 2014 survey was timed to coincide with the period when a peak in Arctic meltwater moves down the Labrador Shelf, the salinity gradient is maximized, and the impact of cross-shelf transport on salinity has the potential to be large. The Labrador Current is undersampled (Dickson et al. 2007; Fratantoni and McCartney 2010); there are few highresolution repeat sections across the current in our study region.

It has long been speculated that freshwater added to the Labrador Sea by, for example, Arctic meltwater could slow convection in the interior, with an associated impact on the Atlantic meridional overturning circulation (AMOC) (Manabe and Stouffer 1997; Renssen et al. 2002; Morrill et al. 2013), though the mechanisms governing the cross-shelf transport of such freshwater have gone largely unobserved. Understanding the mechanisms of freshwater transport across the Labrador shelf break will ultimately help to predict how an increased flux of fresh Arctic meltwater might impact LSW formation and, possibly, the AMOC. There have been many studies of freshwater export through Davis Strait (Loder et al. 1998; Cuny et al. 2005; Curry et al. 2011) and Hudson Strait (Straneo and Saucier 2008) onto the Labrador Shelf, but few have examined how this water might leave the shelf and enter the interior Labrador Sea (Myers 2005; Fratantoni and McCartney 2010). Dickson et al. (2007) cautions that the freshwater budget and exchanges between the Arctic and the North Atlantic may vary under a changing climate. The Grand Banks, which is beyond the southern limit of our glider survey and several hundred kilometers south of the Labrador Sea convection region, is known to be the primary location of freshwater export off the Labrador Shelf (Myers 2005; Fratantoni and McCartney 2010). Here, the Labrador Current retroflects as it encounters and mixes with the North Atlantic Current flowing eastward across the Atlantic (Smith et al. 1937; Csanady and Hamilton 1988; Fratantoni and McCartney 2010). Therefore, freshwater exported from the shelf at the tail of the Grand Banks is likely to take a longer, slower pathway to the Labrador Sea convective region and experience greater mixing and dilution along that pathway than freshwater transported across the shelf break in our study region. 
In addition to assessing the lateral transport of freshwater, we also quantify the lateral supply of oxygen and evaluate its potential importance to the oxygen budget of the interior Labrador Sea. While many studies assume an oxygen budget that is dominated by vertical fluxes and biological processes (e.g., Körtzinger et al. 2001; Nicholson et al. 2008), others have shown that lateral transport can be a critical component in the budget (e.g., Stramma et al. 2010). The role that lateral fluxes play in the oxygen budget depends on location, and we seek to add clarity to this discussion for the western Labrador Sea. Though the obtained glider data limit our quantification to the Ekman and eddy cross-shelf transport, we acknowledge that there are other potential transport terms to consider in the mass budget, such as bottom boundary layer transport (Thompson et al. 2014), convergence of the along-shelf transport on the Labrador Shelf, onshore geostrophic flow resulting from an alongshelf pressure gradient (Stommel and Leetmaa 1972; McCabe et al. 2015), and/or deep across-shelf transport and upwelling due to the eddy- and wind-driven divergence on shelf. Nevertheless, this study reveals the nature and magnitude of two of the most important exchange mechanisms across the Labrador Current, the dynamical boundary between the Labrador Shelf and Sea.

In section 2, we describe the field campaign in more detail, along with the methods for calibrating the glider data and analyzing them to quantify cross-shelf exchange of mass, freshwater, and oxygen. In section 3, we describe the hydrography of the Labrador shelf break, including observations of two small, deep-reaching eddies. In section 4 , we elucidate the mechanisms of cross-shelf transport in the context of previous studies. Section 5 concludes by relating the transport results to its potential influence on convection.

\section{Methodology}

\section{a. Field campaign}

We deployed two Slocum 1000-m gliders (named Unit 473 and Pearldiver) in the Labrador Sea from the Canadian Coast Guard Ship (CCGS) Hudson. The gliders made multiple transects across the shelf break between 5 July and 22 August 2014 (Fig. 1). Both gliders were equipped with SeaBird Electronics pumped CTDs and Aanderaa 4831 oxygen optodes. The gliders were programmed to cross the Labrador Current at approximately right angles to the shelf break, and both gliders made five successful cross-current sections. Unit 473 made an additional section of a mesoscale eddy without crossing the shelf break. On average, the gliders traversed laterally $4 \mathrm{~km}$ for each vertical dive-climb cycle of $1000 \mathrm{~m}$. Each cross-shelf section was approximately $100 \mathrm{~km}$ in length and took 5 days to traverse, with 1-2 days in the core of the Labrador Current (where vertically averaged velocity is above $0.15 \mathrm{~m} \mathrm{~s}^{-1}$ ). Thus, each section was treated as a snapshot in time of the current system. This treatment should be viewed with some caution, as we observed eddies that were about $20 \mathrm{~km}$ in diameter and background flow speeds in the shelf-break current of up to $0.2 \mathrm{~m} \mathrm{~s}^{-1}$. Therefore an eddy could pass a fixed location in a day, more quickly than our glider was able to traverse the entire section. However, the presence of coherent vortices on two sections was apparent in the velocity and property fields, so we could readily distinguish these features from the more slowly varying shelf-break current.

The mission ended when the gliders encountered a buoyant layer of surface water that prevented them from surfacing. The loss of Iridium and GPS communications while trapped beneath the surface triggered the gliders to drop their ejection weights, allowing them to surface, and thereby ending the mission. Both gliders were recovered on 22 August 2014 with the help of a fishing vessel. Even with the mission thus shortened, we collected 1982 profiles during the 7 -week survey, which is about $20 \%$ as many profiles as had been collected in the region during the entire century preceding the survey (Fratantoni and McCartney 2010). The resolution provided by the glider data was critical in assessing the buoyancy gradients that give rise to baroclinic eddies, which is difficult to achieve with the spatial density of traditional mooring arrays and hydrographic surveys in this region.

\section{b. Data correction and calibration}

Seabird oxygen, bottle oxygen, and CTD data collected from the rosette of the CCGS Hudson before the gliders' deployment provided the data to calibrate the glider sensors. These ship-based calibration casts were collected $4.6 \mathrm{~h}$ before and $2.9 \mathrm{~km}$ from Pearldiver's first profile and $6.5 \mathrm{~h}$ before and $1.5 \mathrm{~km}$ from Unit 473 's first profile. Before correcting the glider profiles with the ship-based calibration casts, we first correct for inaccuracies due to the sensor response time, as described below.

\section{1) SENSOR RESPONSE TIME CORRECTION}

When the sensor response time is slow relative to the diving rate of the glider, the sensor misses high-frequency excursions in the properties it measures. This is especially true for the oxygen optodes (Nicholson et al. 2008). Therefore, to better capture higher-frequency excursions in the temperature, salinity, and oxygen $\left(T, S\right.$, and $\left.\mathrm{O}_{2}\right)$ profiles, first-order lag is corrected as in Fofonoff et al. (1974) by calculating $\tau$ in the equation: 


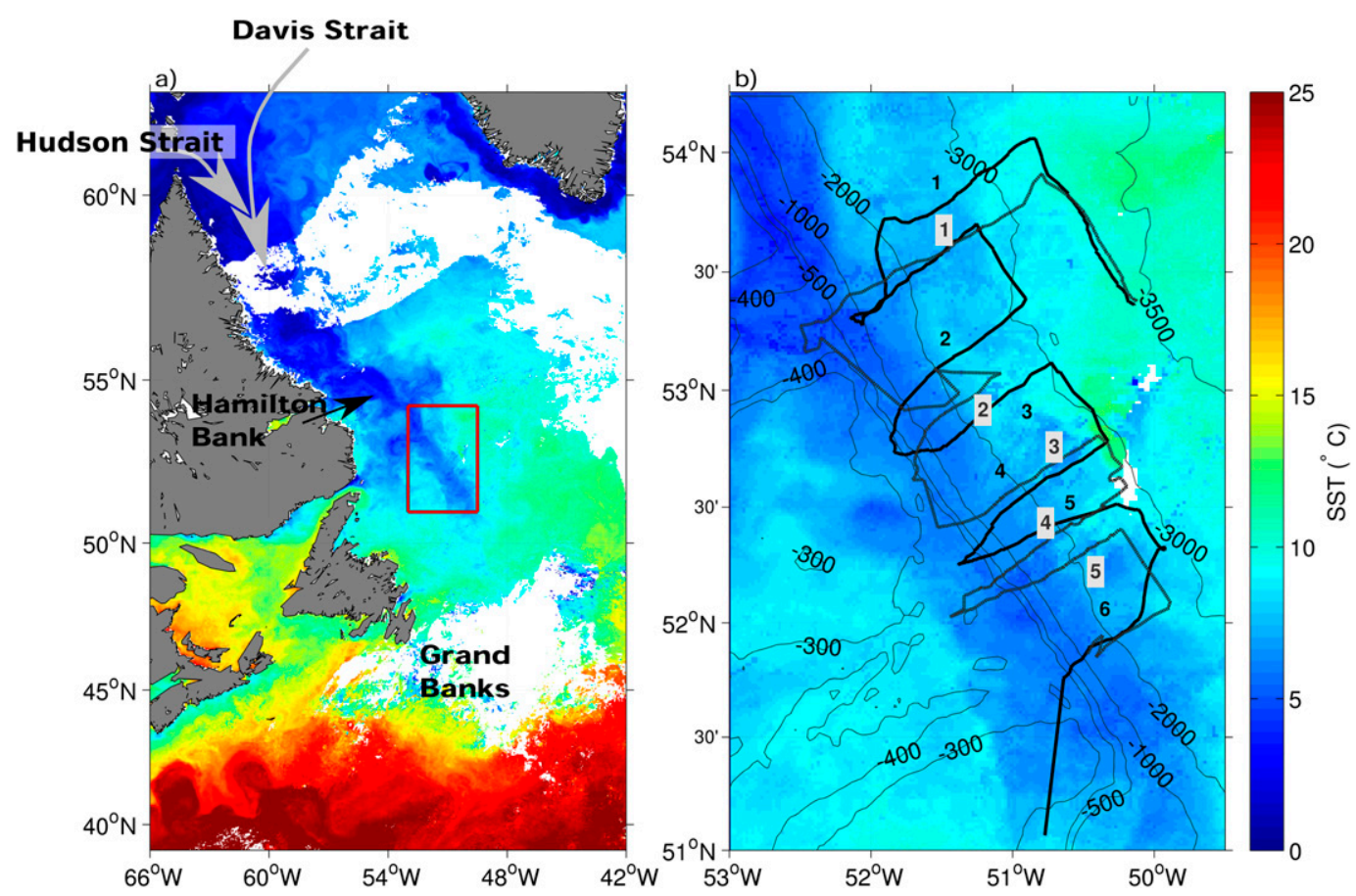

FIG. 1. (a) Map of SST showing the cold Labrador Current along the shelf break. White pixels are cloud-covered regions. Flow through Hudson and Davis Straits are indicated by the gray arrows. Bathymetric features of Hamilton Bank and Grand Banks are also labeled. (b) Map of SST from the red box in (a) with isobaths (m) and trajectories of Unit 473 (black) and Pearldiver (gray) from 5 July to 22 August 2014. The bold numbers correspond to the sections occupied by the gliders. The ETOPO2 bathymetry was used. SST data cover the 9-15 July 2014 period and were provided by Carla Caverhill from the Department of Fisheries and Oceans Canada.

$$
X_{\text {true }}=X_{\text {measured }}+\tau \frac{d}{d t} X_{\text {measured }},
$$

where $X_{\text {true }}$ is the true value of temperature, conductivity, or oxygen phase and $X_{\text {measured }}$ is the measured value. Derivatives were calculated using a centered difference scheme after interpolating upcast and downcast values to the same depths. To solve this equation, the error between upcast and downcast values was minimized as follows. For any variable $X$ there are two equations: one for all upcast values and one for all downcast values. These two equations are rearranged for $X_{\text {measured }}$ and then subtracted:

$$
\begin{aligned}
X_{\text {measured }}^{\text {upcast }}-X_{\text {measured }}^{\text {downcast }}= & X_{\text {true }}^{\text {upcast }}-X_{\text {true }}^{\text {downcast }} \\
& -\tau\left(\frac{d}{d t} X_{\text {measured }}^{\text {upcast }}-\frac{d}{d t} X_{\text {measured }}^{\text {downcast }}\right),
\end{aligned}
$$

where $\tau$, the response time constant, can be solved using a least squares regression, under the assumption that adjacent upcast and downcasts are identical (i.e., $X_{\text {true }}^{\text {upcast }}-X_{\text {true }}^{\text {downcast }}=0$ ). This is a reasonable approximation as the maximum distance between adjacent points on an upcast-downcast pair for a 1000 -m glider dive is
$5 \mathrm{~km}$, which is about a factor of 5 shorter than the decorrelation length scale in the region (Lavender et al. 2005). Table 1 shows the values of $\tau$ and their $95 \%$ confidence intervals.

Next, glider temperature and salinity profiles collected most closely to the CCGS Hudson calibration cast were compared against the ship's CTD using a linear regression (Table 2). Ultimately, we opted not to use the $T$ and $S$ corrections from the ship-based calibration, because the RMS error of the glider $T$ and $S$ profiles to the ship-based profiles was either marginally improved or essentially unchanged (Table 2). Moreover, the small differences between the glider and ship-based profiles could arise due to real differences between the profiles, given that they were separated in space and time. Results of the calibration on the initial casts can be seen in Fig. 2 .

\section{2) OXYGEN OPTODE CORRECTIONS}

After correcting the optode phase data for the slow response time using Eq. (2), we calculate the oxygen concentrations. Although the optode outputs nominal oxygen concentrations, these have known errors due to the assumption of a constant and arbitrary salinity value and the use of a temperature sensor that is insulated 
TABLE 1. Values of $\tau$ with 95\% confidence intervals and RMS errors between upcast and downcast values both before and after sensor response time correction as defined in Eq. (2) in the text.

\begin{tabular}{lcccc}
\hline \hline & & & \multicolumn{2}{c}{ RMS error } \\
\cline { 4 - 5 } & $\tau(\mathrm{s})$ & $95 \%$ confidence interval & Before correction & After correction \\
\hline Unit 473 & & & 0.268 & 0.238 \\
Temperature & 1.97 & $1.93-2.02$ & 0.024 & 0.021 \\
Conductivity & 2.37 & $2.32-2.41$ & 0.322 & 0.177 \\
Oxygen phase & 35.38 & $35.29-35.46$ & & 0.311 \\
\hline Pearldiver & & & 0.028 & 0.027 \\
Temperature & 1.76 & $1.73-1.80$ & 0.344 & 0.223 \\
Conductivity & 1.93 & $1.89-1.96$ & & \\
Oxygen phase & 33.88 & $33.81-33.95$ & &
\end{tabular}

within the optode, giving it a slow response time. Thus, we calculate oxygen concentrations using the responsetime-corrected optode phase data and the responsetime-corrected CTD temperature and absolute salinity, the latter calculated from the glider CTD conductivity (IOC et al. 2010; McDougall and Barker 2011). The oxygen concentrations were then calculated based on the multistep methodology described in the Aanderaa 4831 optode manual (Aanderaa Data Instruments 2014).

Finally, the response-time-corrected oxygen casts are compared against the calibration cast from the CCGS Hudson. As noted above, this calibration cast is separated in space and time from the glider casts. Therefore, the oxygen data were calibrated with the ship-based data in potential density $\left(\sigma_{\theta}\right)$ space to eliminate differences between the profiles due to heaving isopycnals from, for example, internal waves. Following calibration with the CCGS Hudson data in $\sigma_{\theta}$ space using linear regression, oxygen was returned to depth space for plotting. The uncalibrated glider optodes were offset by about 10 and $20 \mathrm{mmol} \mathrm{m}^{-3}$ for Unit 473 and Pearldiver, respectively, (Fig. 2) relative to the shipbased, SeaBird oxygen sensor measurements, which were themselves calibrated using Winkler titrations. The optodes were found to drift linearly after deployment. Using a linear regression of $\mathrm{O}_{2}$ concentration versus time on a deep isopycnal layer bounded between 27.71 and $27.72 \mathrm{~kg} \mathrm{~m}^{-3}$, we estimated the drift to be $-0.56 \mathrm{mmol} \mathrm{m}^{-3}$ day $^{-1}$ (with correlation coefficient $R^{2}=0.87$ ) for Unit 473 and $-0.21 \mathrm{mmol} \mathrm{m}^{-3}$ day $^{-1}\left(R^{2}=0.59\right)$ for Pearldiver, a decline of about $0.1 \%$ of the observed oxygen values each day. We removed these linear drifts in the results that follow.

\section{3) CReating CRoss-SHelf SECTIONS}

The data were gridded through linear interpolation with a grid spacing of $3 \mathrm{~m}$ in the vertical and $0.5 \mathrm{~km}$ in the horizontal along track distance. This horizontal resolution was necessary to prevent degradation of the data during shallow dives and near glider inflection points. The gridded data were then smoothed using a boxcar filter that extends $15 \mathrm{~m}$ in the vertical and $5 \mathrm{~km}$ in the horizontal (5 grid points in the vertical and 10 grid points in the horizontal). Our results and interpretation are robust across smoothing length scales: a sensitivity analysis using a boxcar smoother of $2.5,3.5$, or $5 \mathrm{~km}$ in the horizontal changes our eddy flux calculation by approximately $10 \%$.

TABLE 2. Calibration with Hudson: $X_{\text {Hudson }}=a+b X_{\text {glider }}$. RMS error calculated using Hudson data and glider data before and after calibration. Parameter $a$ has units of ${ }^{\circ} \mathrm{C}$ for temperature and $\mathrm{mmol} \mathrm{m}^{-3}$ for oxygen.

\begin{tabular}{|c|c|c|c|c|c|c|}
\hline & \multirow[b]{2}{*}{$a$} & \multirow[b]{2}{*}{$b$} & \multicolumn{2}{|c|}{$95 \%$ confidence intervals } & \multicolumn{2}{|c|}{ RMS error } \\
\hline & & & $a$ & $b$ & Before calibration & After calibration \\
\hline \multicolumn{7}{|l|}{ Unit 473} \\
\hline Temperature & 0.38 & 0.92 & $0.32-0.44$ & $0.91-0.93$ & 0.213 & 0.186 \\
\hline Salinity & 0.70 & 0.98 & $-0.34-1.73$ & $0.95-1.01$ & 0.019 & 0.019 \\
\hline Oxygen & -58.07 & 1.22 & $-83.36--32.78$ & $1.13-1.30$ & 8.325 & 4.896 \\
\hline \multicolumn{7}{|l|}{ Pearldiver } \\
\hline Temperature & 0.36 & 0.90 & $0.30-0.41$ & $0.88-0.91$ & 0.199 & 0.152 \\
\hline Salinity & 5.34 & 0.85 & $4.81-5.87$ & $0.83-0.86$ & 0.014 & 0.010 \\
\hline Oxygen & 58.33 & 0.86 & $49.20-67.46$ & $0.82-0.89$ & 17.958 & 2.712 \\
\hline
\end{tabular}



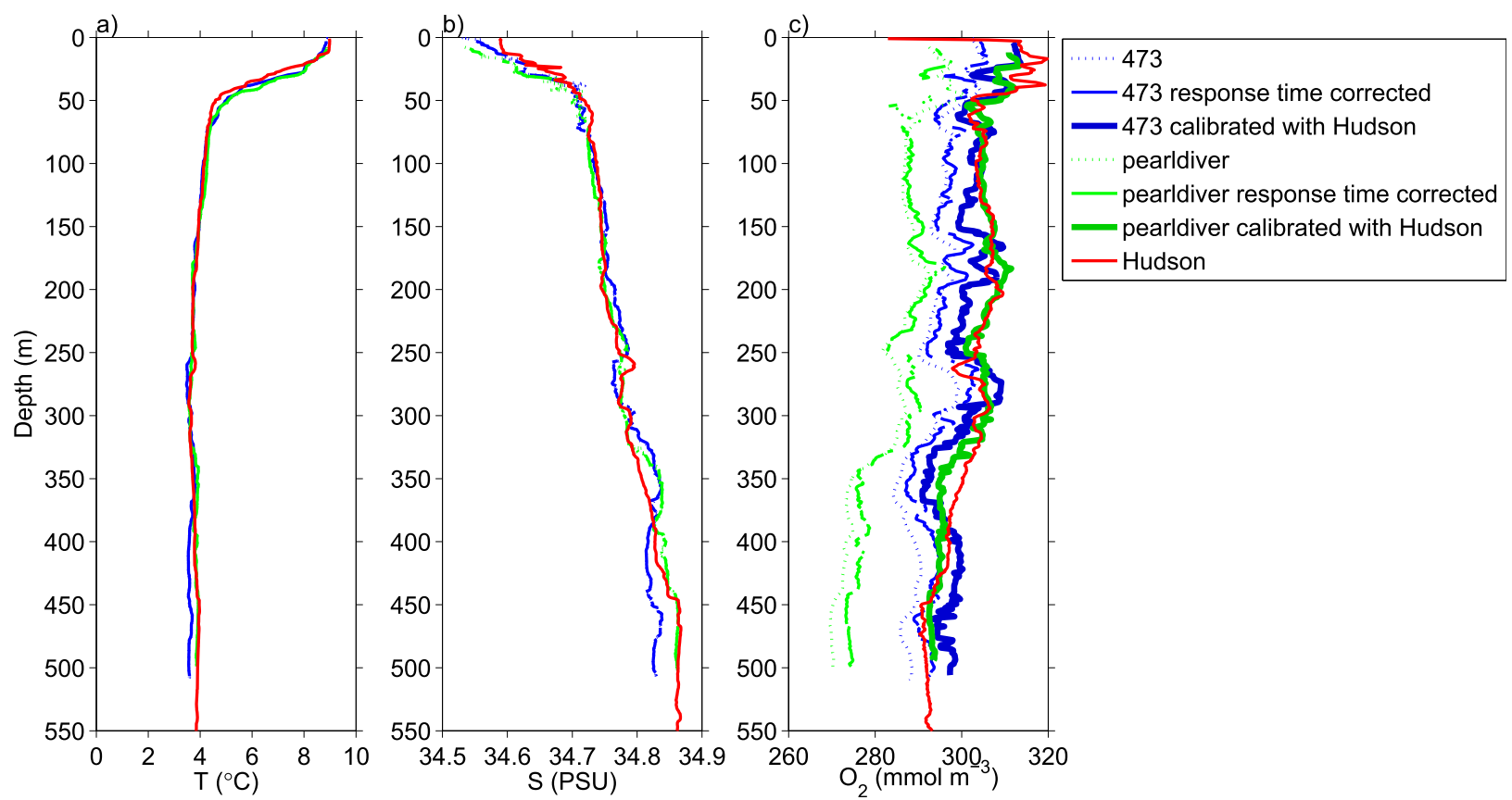

FIG. 2. Calibration profiles during deployment: ship-based CTD from the CCGS Hudson (red) and the two gliders (blue and green). The dotted lines show the raw glider data. The thin solid lines for (a) temperature and (b) practical salinity show the data with the response time correction, as in Eq. (2). For (c) oxygen, the thin line has sensor response time corrections applied to the raw phase data, temperature, and salinity along with salinity and pressure compensations as outlined in Aanderaa Data Instruments (2014). The bolder lines in (c) show the final calibration with the CCGS Hudson profile.

\section{c. Quantification of transports}

\section{1) SURFACE EKMAN LAYER TRANSPORT}

The surface Ekman transport was scaled based on satellite wind stress data provided by the Centre de Recherche et d'Exploitation Satellitaire (CERSAT), at Institut Français de Recherche pour l'Exploitation de la Mer (IFREMER), Plouzané (France). These data were collected by the Advanced Scatterometer (ASCAT) aboard the Metop satellite, which samples the study region more than once per day. Daily averaged wind stress with a spatial resolution of $0.25^{\circ}$ was used (Bentamy and Fillon 2012).

The wind stress within the study region was interpolated to a linear approximation of the 500-m isobath (Fig. 3) and projected into along- and cross-isobath components $\boldsymbol{\tau}_{\|}, \boldsymbol{\tau}_{\perp}$ :

$$
\boldsymbol{\tau}_{\|}=\mathbf{R} \frac{\mathbf{R} \cdot \boldsymbol{\tau}}{|\mathbf{R}|^{2}}, \quad \tau_{\perp}=\tau-\boldsymbol{\tau}_{\|},
$$

where $\mathbf{R}$ is a vector along the isobath defined by $\mathbf{R}=(\Delta x, \Delta y)$, where $\Delta x$ is the distance between longitudes of the isobath approximation at the midpoint latitude, and $\Delta y$ is the distance between latitudes on the same section of the isobath; $\boldsymbol{\tau}$ is the wind stress vector interpolated to the isobath. Our sign convention takes northward and eastward stresses as positive.

The cross- and alongshore Ekman transport is driven by the wind stress parallel and perpendicular to the slope, respectively:

$$
\mathscr{C}_{\mathrm{Ek}}^{\perp}=\frac{\tau_{\|}}{\rho_{o} f}, \quad \mathscr{C}_{\mathrm{Ek}}^{\|}=\frac{-\tau_{\perp}}{\rho_{o} f},
$$

where $\rho_{o}=1025.67 \mathrm{~kg} \mathrm{~m}^{-3}$ is a reference density taken to be the average density in the top $10 \mathrm{~m}$ from all glider measurements and $f=1.16 \times 10^{-4} \mathrm{~s}^{-1}$ is the mean Coriolis parameter in the study region. The uncertainty in the Ekman mass transport was taken to be the standard deviation of all transport values along the 500-m isobath and over the study period.

\section{2) Transport due to Mesoscale EDdiES}

Mass transport due to mesoscale eddies arises when velocity anomalies on an isopycnal layer are correlated with thickness anomalies of that layer. Here, thickness is defined as the vertical distance between two isopycnals. The eddy flux can be represented by the $\overline{u^{\prime} h^{\prime}}$ term in the Reynolds averaged, shallow water, mass continuity equation with $u^{\prime}$ and $h^{\prime}$ being the respective velocity and thickness perturbations from the mean. Our glider survey did not sample the region long enough to get a 

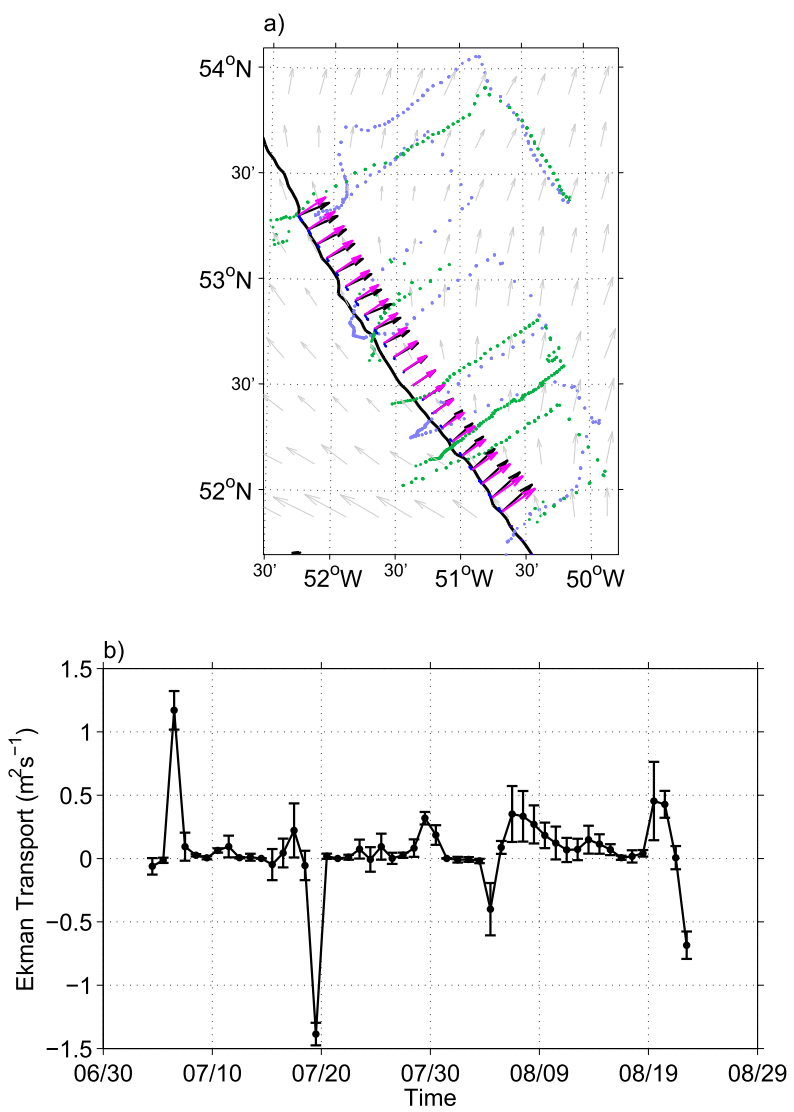

FIG. 3. (a) Temporally averaged map of wind stress over the study period (light gray arrows) with the net Ekman transport (black) and cross-shelf Ekman transport (magenta). The glider trajectories are also shown by the faint blue and green dots. The thick black line is the 500-m isobath from the ETOPO2 bathymetry. (b) Time series of spatially averaged cross-shelf Ekman transport between 5 July and 22 August 2014 with error bars representing two standard deviations. The mean transport is $0.05 \mathrm{~m}^{2} \mathrm{~s}^{-1}$.

robust estimate of the net flux due to eddying motions. Hence, an eddy transport closure is required. This closure is often assumed proportional to the thickness gradient and an eddy diffusivity (Gent and McWilliams 1990):

$$
\mathscr{C}_{e}=\overline{u^{\prime} h^{\prime}}=u_{b} \bar{h}=-K \frac{\partial \bar{h}}{\partial x},
$$

where $u_{b}=\overline{u^{\prime} h^{\prime}} / \bar{h}$ is the eddy-induced or bolus velocity perpendicular to the isobaths (Rhines 1982) and $\partial \bar{h} / \partial x$ is the cross-shelf thickness gradient of an isopycnal layer, with $\bar{h}$ averaged over time and over mesoscale zonal fluctuations with a $9.5-\mathrm{km}$ running mean. The variable $K$ represents the eddy diffusivity estimated using a parameterization from Visbeck et al. (1997):

$$
K=\alpha \frac{M^{2}}{N} \ell^{2},
$$

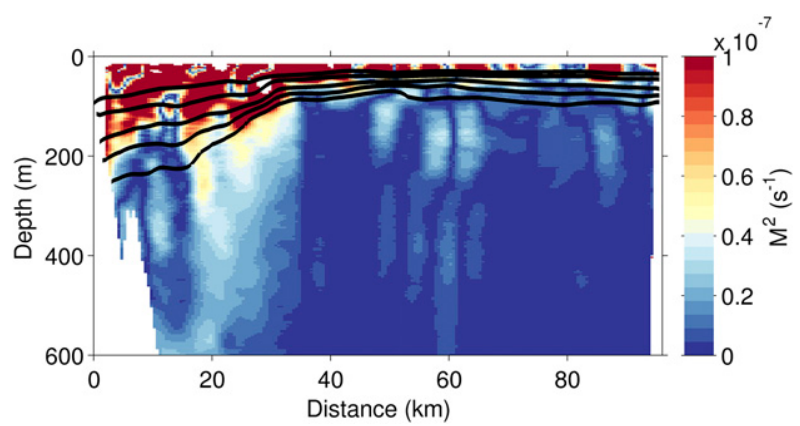

FIG. 4. A typical cross section (Unit 473, section 2) of the lateral buoyancy gradient $M^{2}$. The isopycnals $\sigma_{\theta}=27.20,27.41,27.55,27.60$, and $27.63 \mathrm{~kg} \mathrm{~m}^{-3}$ are contoured in black. The white region at the bottom left is beneath the deepest glider profile and approximates the bathymetry where it is shallower than $1000 \mathrm{~m}$. The shelf break is at $500-\mathrm{m}$ depth.

where $M^{2}=|\partial b / \partial x|$ and $N^{2}=\partial b / \partial z$ are the lateral and vertical buoyancy gradients with $b=-g\left(\rho-\rho_{o}\right) / \rho_{o}$ and where $g$ is the gravitational acceleration, $\rho$ is the density, and $\rho_{o}$ is a reference density. Here, $\alpha=0.015$ is a proportionality constant. Finally, $\ell$ is the horizontal length scale of the baroclinic front, and picking the appropriate length scale is a major source of uncertainty in the calculation of the eddy transport term. We use a value for $\ell$ of $20 \mathrm{~km}$, the width of the region over the shelf break with the largest $M^{2}$ (Fig. 4). The large lateral buoyancy gradient indicates the region where isopycnals are vertically tilted (i.e., where they are most baroclinic). For comparison, we calculated the first baroclinic deformation radius for a two-layer system: $L_{D}=\sqrt{g\left(\rho_{2}-\rho_{1}\right) H_{1} H_{2} /\left[\rho_{1}\left(H_{1}+H_{2}\right)\right]} / f$ (Cushman-Roisin and Beckers 2011). We simplified our system into two dynamically different layers: the thermocline to the surface $\left(H_{1}=300 \mathrm{~m}, \rho_{1}=1027.34 \mathrm{~kg} \mathrm{~m}^{-3}\right)$ and a lessstratified bottom layer that extends down to the $500-\mathrm{m}$ isobath $\left(H_{2}=200 \mathrm{~m}, \rho_{2}=1027.67 \mathrm{~kg} \mathrm{~m}^{-3}\right)$. This gives a deformation radius of $5 \mathrm{~km}$, about one quarter of the chosen baroclinic length scale.

All negative values of $N^{2}$ were removed as these are likely due to small-scale noise in the glider CTD; these values represented about $0.2 \%$ of the dataset. In any case, any true unstable stratification would be mixed through static instability much faster than the growth rate of baroclinic instability. We also removed values that were greater than three standard deviations from the mean, about $2 \%$ of the dataset, as these were outliers in our dataset.

We evaluated the right-hand side of Eq. (6) on four isopycnal layers bounded by $\sigma_{\theta}=27.20,27.41,27.55$, 27.60 , and $27.63 \mathrm{~kg} \mathrm{~m}^{-3}$ (Fig. 5). These isopycnals covered most of the water column in the shelf-break region without outcropping at the surface or intersecting the topography. The thickness gradient was taken as the average within the $25-\mathrm{km}$ box positioned $5 \mathrm{~km}$ onshore 

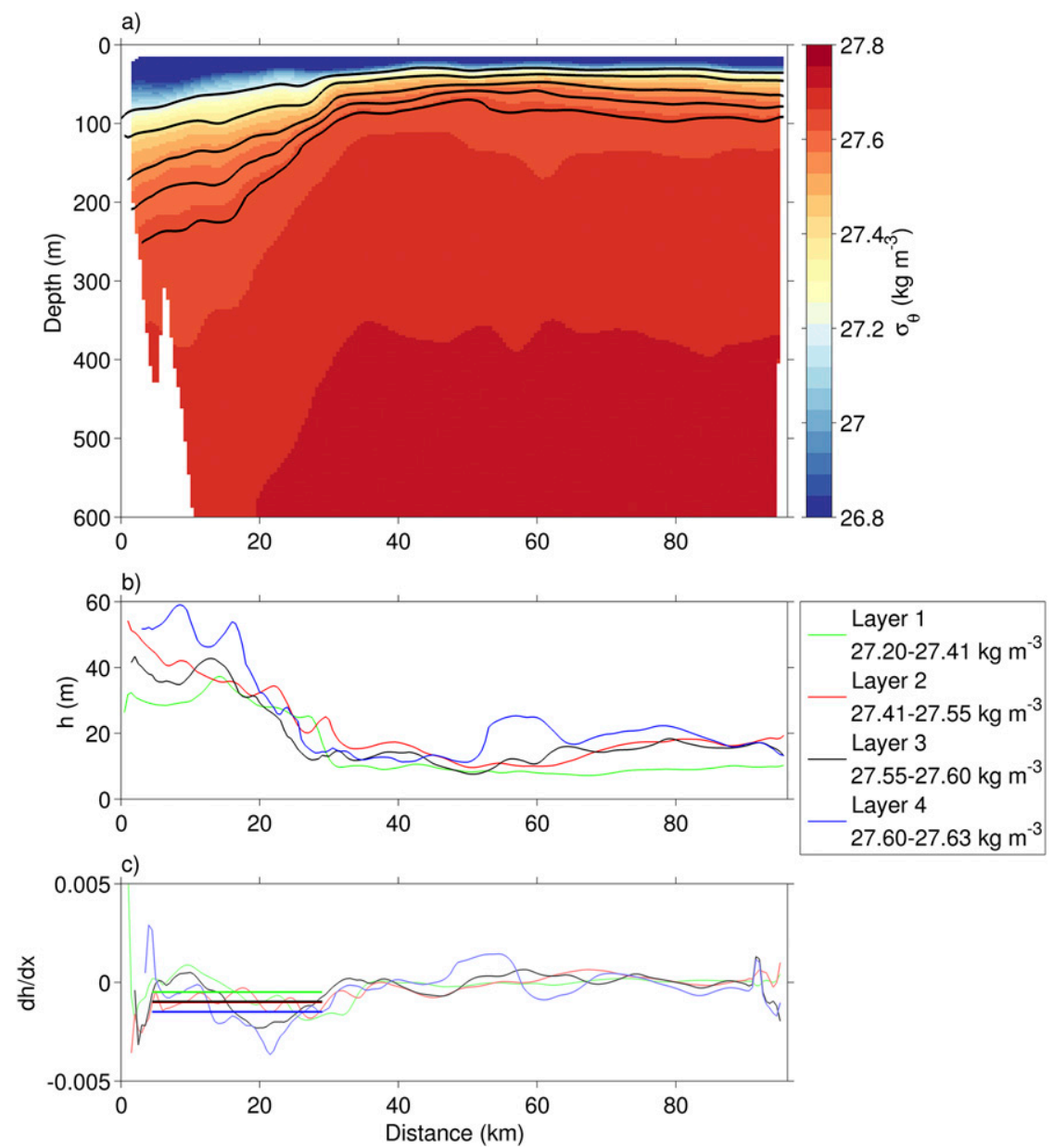

Fig. 5. (a) A typical $\sigma_{\theta}$ cross section (Unit 473, section 2) with $\sigma_{\theta}=27.20,27.41,27.55,27.60$, and $27.63 \mathrm{~kg} \mathrm{~m}^{-3}$ contoured in black, illustrating the four isopycnal layers used in the eddy transport calculations. (b) The thickness of each isopycnal layer. (c) The thickness gradient of $\bar{h}$. Thick lines indicate the average within each layer over the $25-\mathrm{km}$ box over the shelf break. The shelf break is at 500-m depth.

and $20 \mathrm{~km}$ offshore over the $500-\mathrm{m}$ isobath for each cross-slope section (Fig. 5c). Likewise, an average value of $K$ was taken in each of these layers within the same $25-\mathrm{km}$ bin. These values were then used in the eddy transport scaling [Eq. (6)], and averaged over all cross sections for the net eddy transport in each layer.

The uncertainty in the eddy mass transport was calculated by propagating the standard deviation of $K$ and $\partial \bar{h} / \partial x$ within each isopycnal layer in the $25-\mathrm{km}$ box over the 500-m isobath (e.g., Bevington 1969, 56-65). Further discussion of the uncertainty in these calculations is provided in section $4 \mathrm{a}$.

\section{3) FRESHWATER AND OXYGEN TRANSPORTS}

The tracer conservation equation decomposed into the thickness-weighted average and perturbation $\left(C=\hat{C}+C^{\prime \prime}\right)$ provides a framework for quantifying tracer transport within isopycnal layers of variable thickness (Griffies 2004; Young 2012):

$$
\frac{\partial(\bar{h} \hat{C})}{\partial t}+\nabla \cdot(\bar{h} \hat{C} \hat{\mathbf{u}})=-\nabla \cdot\left(\bar{h} \widehat{C^{\prime \prime} \mathbf{u}^{\prime \prime}}\right)
$$

where the $\widehat{[]}$ operator indicates a thickness-weighted averaged value (e.g., $\hat{C}=\overline{h C} / \bar{h}$ ), the thickness-weighted concentration of tracer $C$. The deviation from this mean is denoted by double primes (e.g., $\left.C^{\prime \prime}\right)$. Here, $\hat{\mathbf{u}}$ is the thickness-weighted average of the velocity vector, and $\bar{h}$ is the average isopycnal thickness of the $25-\mathrm{km}$ region around the 500-m isobath.

The full thickness-weighted velocity field $\hat{\mathbf{u}}$ responsible for the advective transport of all tracers includes contributions from the mean and bolus velocities $\left[\hat{\mathbf{u}}=\overline{\mathbf{u}}+\mathbf{u}_{b}\right.$; see Eq. (6)]. In addition, eddy-induced 
tracer transport can arise as a result of correlations of the tracer concentration and velocity perturbations, with this term often represented with a similar downgradient diffusion closure; in the cross-shelf direction, this becomes

$$
\widehat{C^{\prime \prime} u^{\prime \prime}}=-K \frac{\partial \hat{C}}{\partial x}
$$

where $K$ is the eddy diffusivity, which we assume is equal to the one solved for in Eq. (7).

Thus, combining Eqs. (6) and (8), and further assuming that the mean flow perpendicular to the shelf break is due principally to Ekman transport [a common assumption for flow across a boundary current that cannot support a time-mean pressure gradient in the alongcurrent direction, i.e., when there are no meridional bathymetric boundaries (e.g., Thompson et al. 2014)], the net transport of tracer across the shelf break is given by

$$
T_{C}=\mathscr{C l}_{\mathrm{Ek}} \hat{C}-K\left(\hat{C} \frac{\partial \bar{h}}{\partial x}+\bar{h} \frac{\partial \hat{C}}{\partial x}\right)
$$

The thickness gradient associated with the bolus velocity as calculated in Eq. (6) is averaged within each isopycnal layer and within the $25-\mathrm{km}$ box over the $500-\mathrm{m}$ isobath. This $25-\mathrm{km}$ width is on the same order as the baroclinic length scale. The generic tracer $\hat{C}$ is replaced by either the thickness-weighted salinity anomaly or thickness-weighted oxygen concentration. The salinity anomaly is defined as $S_{a}=\left(S_{\text {ref }}-S\right) / S_{\text {ref }}$, where $S$ is the measured salinity and $S_{\text {ref }}=34.8$ is a reference salinity set equal to the average salinity over all glider salinity measurements. To calculate the eddy-driven tracer transport, the thickness-weighted average $\hat{S}_{a}$ is also averaged in the $25-\mathrm{km}$ box over the shelf break. For the Ekman-driven transport, $S_{a_{\mathrm{Ek}}}$ was taken as a weighted average over the top $100 \mathrm{~m}$, where weights were defined by an exponentially decaying function with an $e$-folding scale of $22.1 \mathrm{~m}$ to mimic the velocity decay within the Ekman layer (Lenn and Chereskin 2009; Palter et al. 2013) and averaged in a $9.5-\mathrm{km}$ box centered over the 500-m isobath. We estimated the net transport of freshwater by averaging over all cross sections and multiplying by the $700-\mathrm{km}$ length of shelf break that has similar characteristics to our $150-\mathrm{km}$ glider study region (i.e., where the shelf break has a similar slope and is relatively straight). Convection in the Labrador Sea has been observed adjacent to the northern extension of the $700-\mathrm{km}$ stretch of shelf break. The oxygen transport across the shelf break was estimated in a similar manner except using $\left[\hat{\mathrm{O}}_{2}\right]$.

The uncertainty in the eddy-driven tracer transport was calculated by propagating the standard deviation of
$K, \bar{h}, \partial \bar{h} / \partial x, \hat{S}_{a}, \partial \hat{S}_{a} / \partial x,\left[\hat{\mathrm{O}}_{2}\right]$, and $\partial\left[\hat{\mathrm{O}}_{2}\right] / \partial x$ within each isopycnal layer in the $25-\mathrm{km}$ box over the $500-\mathrm{m}$ isobath.

\section{Hydrography of the Labrador shelf break}

The hydrography of the study region during our survey is characterized in Fig. 6, which shows two representative sections made by Unit 473. All other sections are shown in the supplemental material. Section 1 (Figs. 6a-d) does not fully traverse the shelf break, but rather sampled one of two cyclonic eddies discovered during the survey, described in more detail below. Section 2 (Figs. 6e-h) extends onto the shelf until encountering a water depth of just less than $300 \mathrm{~m}$.

The current system flowing around the boundary of the Labrador Sea is known to transport cold, fresh, oxygenated water of Arctic origin on its inshore edge and warmer, saltier, lower-oxygen Irminger Water, ultimately of subtropical origin, over the shelf break (Loder et al. 1998; Yashayaev and Loder 2016, 2017). In climatological studies, the signature of the Irminger Water has been shown to erode with distance downstream from the West Greenland Shelf toward the Labrador Shelf, disappearing entirely in the several hundred kilometers separating Labrador from Newfoundland, a region encompassing our glider survey (Fratantoni and Pickart 2007). The erosion of this warm, salty Irminger Water is thought to be a sign of mixing with colder, fresher water, which we attempt to quantify below. Our sections, as exemplified in Fig. 6, confirm the presence of water of cold $\left(-1.5^{\circ}-2^{\circ} \mathrm{C}\right)$, fresh (31-34.2 $\left.\mathrm{g} \mathrm{kg}^{-1}\right)$, oxygenated $\left(310-450 \mathrm{mmol} \mathrm{m}^{-3} ; \geq 95 \%\right.$ saturation) water of Arctic origin in the top $200 \mathrm{~m}$ on the Labrador Shelf, with possible contributions from the cold intermediate layer (CIL) formed locally on the Labrador Shelf (Drinkwater 1996). Beneath this water mass, a bolus of warm $\left(T>4^{\circ} \mathrm{C}\right)$, salty $\left(S>34.9 \mathrm{~g} \mathrm{~kg}^{-1}\right)$, slightly loweroxygen $\left(\mathrm{O}_{2}<300 \mathrm{mmolm}^{-3} ;<95 \%\right.$ saturation $)$ water centered over the $300-\mathrm{m}$ isobath also suggests the presence of an eroded Irminger Water layer that persists to the southern limit of our survey region.

The magnitude of the depth-averaged velocity from the gliders, averaged over all sections is $0.2 \mathrm{~m} \mathrm{~s}^{-1}$ southward with a standard deviation of $0.1 \mathrm{~m} \mathrm{~s}^{-1}$. Comparable to these glider observations, Fratantoni and Pickart (2007) found the thermal wind velocities range from 0 to $0.25 \mathrm{~m} \mathrm{~s}^{-1}$ southward, using an assumed level of no motion at $800 \mathrm{~m}$ applied to a section across the Labrador shelf break near our study region. Transects of depthaveraged velocity show that for most sections (e.g., Unit 473 section 2 in Fig. 6e) the maximum speed is located near the shelf break at approximately the 500-m isobath and is southward, indicating the location of the Labrador Current. However, glider sections that continued onto 

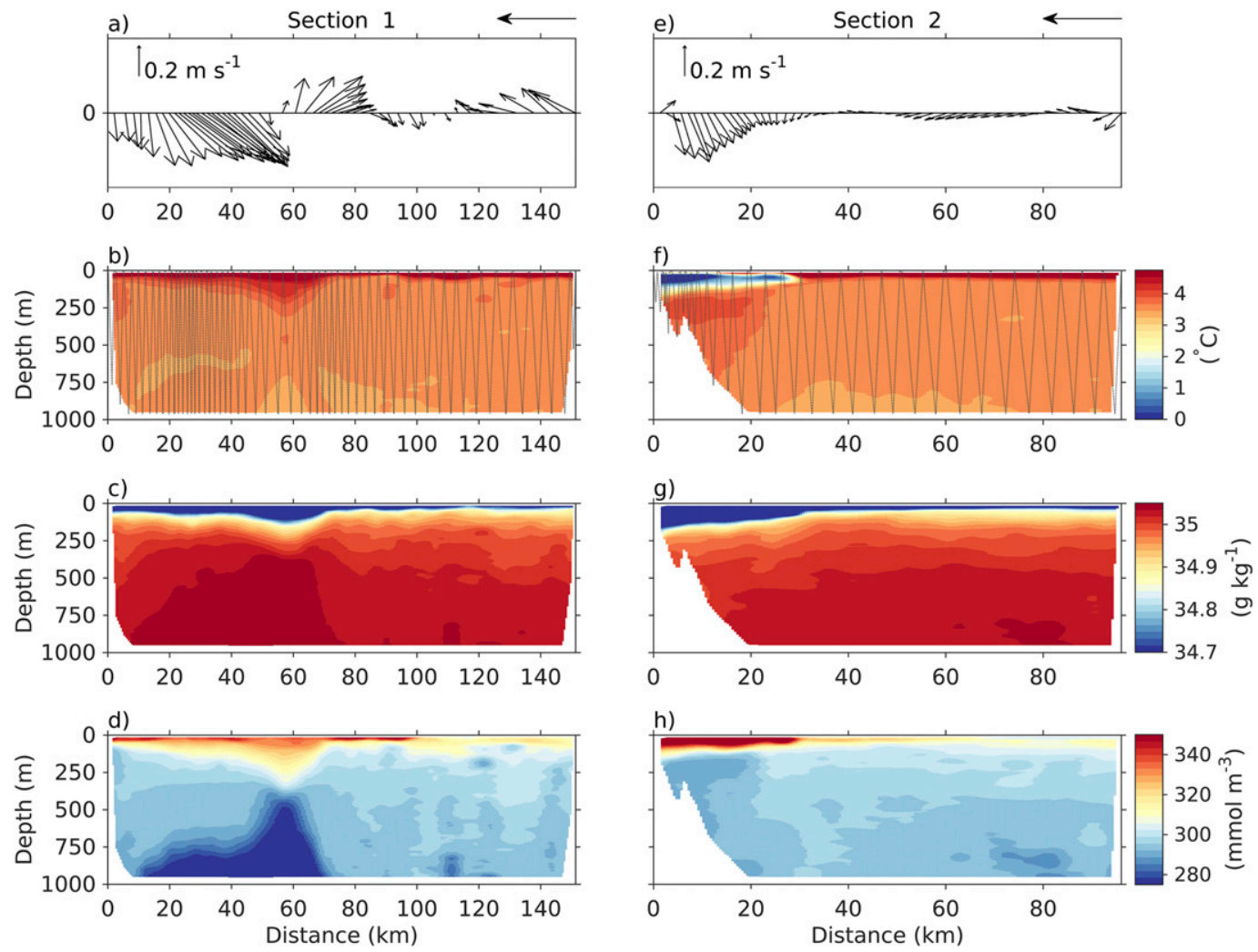

FIG. 6. Unit 473 cross sections of (a),(e) depth-averaged velocity, with positive arrows indicating velocities to the north and/or east and negative arrows to the south and/or west, (b),(f) conservative temperature (IOC et al. 2010), (c),(g) absolute salinity, and (d),(h) oxygen. (left) Section 1 and (right) section 2, with the geographic location of these sections shown in Fig. 1. The gray dotted lines in (b) and (f) indicate the path of the glider, and the black arrow in the top right of (a) and (e) indicates the glider direction when making the section. The glider did not cross the shelf break in section 1 , and the observed high velocities at $50 \mathrm{~km}$ are associated with a cyclonic eddy.

the shelf measured substantial southward velocities even in their most shoreward profile, providing no clear boundary for the current on its shallow side (Fig. 6).

Unit 473 encountered two cyclonic eddies: the first in section 1 (Fig. 6) and a second in section 6 (supplemental Figs. $3 e-h)$. We were surprised to see these features given that cyclonic eddies have seldom been reported in the western Labrador Sea observations (Lilly et al. 2003). The two eddies were sampled 23 days and $200 \mathrm{~km}$ apart. For the glider to have sampled the same eddy twice would have required its advection along the shelf break at approximately $0.1 \mathrm{~m} \mathrm{~s}^{-1}$, which is possible considering the average observed shelf-break current velocity was $0.15 \mathrm{~m} \mathrm{~s}^{-1}$.

The eddy in section 1 is approximately $25 \mathrm{~km}$ in diameter. The depth-averaged velocity sampled by the glider is assumed to be the eddy swirl velocity, which decreased from $0.3-0.4 \mathrm{~m} \mathrm{~s}^{-1}$ at its edges to zero at its center. The eddy in section 6 was similar: it had a diameter of about $16 \mathrm{~km}$ and maximum speeds at its edges of $0.5 \mathrm{~m} \mathrm{~s}^{-1}$. The estimate of the eddy circumference, from which we calculate the diameter, is based on distance over which the glider traveled in a circular pathway (60 and $25 \mathrm{~km}$ for eddies in sections 1 and 6 , respectively) and the fraction of the whole eddy sampled. These fractions ( $3 / 4$ and $1 / 2$, respectively) are estimated by examining the direction of the depthaveraged velocities along the circular path of the glider and by assuming the full eddy velocities would constitute a closed cyclonic vortex.

The vertical structure of these eddies is intriguing: surface properties are displaced downward by more than $100 \mathrm{~m}$ and deep properties are displaced upward by several hundred meters. With the downward displacement of isopycnals in the top $300 \mathrm{~m}$ of the water column, the geostrophic shear is anticyclonic over much of the water column (not shown). Thus, the depth-averaged cyclonic circulation recorded by the gliders over the top $1000 \mathrm{~m}$ suggests that the eddy velocities persist well beneath $1000 \mathrm{~m}$. Anecdotal evidence for deep cyclonic eddies of this size in this region was recorded by isobaric RAFOS floats deployed at 700 and $1500 \mathrm{~m}$ 
TABLE 3. Summary table of Ekman and eddy mass transport. The four isopycnal layers are bounded by $\sigma_{\theta}=27.20,27.41,27.55$, 27.60 , and $27.63 \mathrm{~kg} \mathrm{~m}^{-3}$. Rounding prevents the summation of the rows from being equal to the listed total.

\begin{tabular}{|c|c|c|}
\hline & $\begin{array}{c}\text { Transport } \\
\left(\mathrm{m}^{2} \mathrm{~s}^{-1}\right)\end{array}$ & $\begin{array}{c}\text { Standard } \\
\text { deviation } \\
\left(\mathrm{m}^{2} \mathrm{~s}^{-1}\right)\end{array}$ \\
\hline $\begin{array}{l}\text { Ekman transport }\left(\mathscr{C l}_{\mathrm{Ek}}\right) \\
\text { Cross shelf }\end{array}$ & 0.05 & 0.31 \\
\hline $\begin{array}{l}\text { Eddy transport }\left(\mathscr{C}_{e}\right) \\
\text { Layer } 1\left(\sigma_{\theta}=27.20-27.41 \mathrm{~kg} \mathrm{~m}^{-3}\right) \\
\text { Layer } 2\left(\sigma_{\theta}=27.41-27.55 \mathrm{~kg} \mathrm{~m}^{-3}\right) \\
\text { Layer } 3\left(\sigma_{\theta}=27.55-27.60 \mathrm{~kg} \mathrm{~m}^{-3}\right) \\
\text { Layer } 4\left(\sigma_{\theta}=27.60-27.63 \mathrm{~kg} \mathrm{~m}^{-3}\right)\end{array}$ & $\begin{array}{l}0.05 \\
0.08 \\
0.08 \\
0.12\end{array}$ & $\begin{array}{l}0.03 \\
0.05 \\
0.03 \\
0.05\end{array}$ \\
\hline Net mass transport & 0.4 & 0.3 \\
\hline
\end{tabular}

as part of the Export Pathways from the Subpolar North Atlantic (ExPath) experiment (Bower et al. 2009), several of which got entrained into cyclonic loops (Furey and Bower 2009).

The eddy oxygen anomalies at depth are dramatic compared with surrounding water at similar depths, with the $\mathrm{O}_{2}$ concentration at $400 \mathrm{~m}$ dipping below $290 \mathrm{mmol} \mathrm{m}^{-3}$ and further declining below $275 \mathrm{mmol} \mathrm{m}^{-3}$ near $1000 \mathrm{~m}$ in the core of the eddy. These concentrations are lower than in any other location or depth sampled by the gliders. To put these anomalies in context, it is useful to note that there is a salty, $\mathrm{O}_{2}$ minimum layer beneath the LSW across the interior Labrador Sea, as seen along the repeat hydrographic section AR7W (Yashayaev and Loder 2016). $\mathrm{O}_{2}$ and salinity concentrations in this layer are similar to those observed at and below $500 \mathrm{~m}$ in the eddy core. However, the depth of the $\mathrm{O}_{2}$ minimum layer in the interior Labrador Sea is typically found beneath $1200 \mathrm{~m}$, with the layer deepening in response to deep wintertime convection and shoaling in its absence (Yashayaev and Loder 2016). Because these eddies are small and their surface temperature signature is subtle, they were not readily detectable in satellite altimetry or SST. Their formation mechanism and impact on tracer transport are intriguing questions beyond the scope of the present study; however, similar features have been discussed in other literature (e.g., McWilliams 1985; Molemaker et al. 2015).

\section{Transport across the shelf break}

\section{a. Mass transport}

During our study period, the winds were to the north on average and drove an offshore Ekman transport, averaging $0.05 \mathrm{~m}^{2} \mathrm{~s}^{-1}$ across the 500-m isobath (Fig. 3

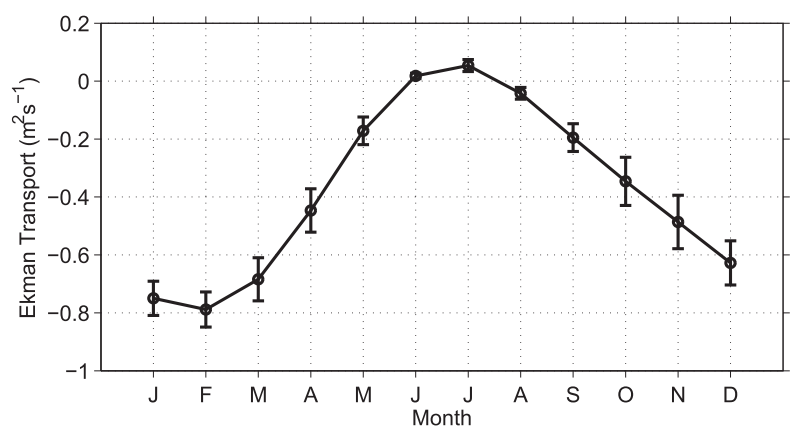

FIG. 7. Time series of spatially averaged cross-shelf Ekman transport along the 500-m isobath in our study region from wind data collected between September 1999 and August 2007 by the scatterometer on the QuikSCAT satellite (Risien and Chelton 2008). Negative transport corresponds with on-shelf Ekman circulation. The error bars indicate two standard deviations.

and Table 3). The Ekman transport has a large standard deviation, primarily caused by two high-wind events. Figure $3 \mathrm{~b}$ shows a time series of cross-shelf Ekman transport over the duration of the mission. During this time, two anomalously windy days are observed, one that leads to strong offshore transport (7 July) and the other to onshore transport (20 July). These two events roughly cancel each other out, leaving the weak mean winds to the north to drive the modest offshore transport. Weak offshore Ekman transport in summer is characteristic of the seasonal climatology (Fig. 7). The northward summertime winds driving this transport are anomalous relative to the annual mean, which is dominated by an atmospheric low pressure system over the subpolar gyre that generates winds blowing toward the south along the Labrador Shelf. During most of the year, these southward winds drive onshore Ekman transport, as illustrated in Fig. 7, and thus our proposed mass balance is relevant to the summertime only.

Eddy-induced transport is proportional to both the isopycnal thickness gradient and eddy diffusivity. Figure 5 shows that the thickness of isopycnal layers is greatest on the shelf and thins moving offshore, going from a thickness of about 20-70 to 10-30 m, depending on the isopycnal layer and cross section. The isopycnals also shoal in the offshore direction by up to $200 \mathrm{~m}$. The average thickness gradient over all sections and layers is $-1 \times 10^{-3}$ with a standard deviation of $1 \times 10^{-3}$. The average eddy diffusivity is $86 \mathrm{~m}^{2} \mathrm{~s}^{-1}$ with a standard deviation of $70 \mathrm{~m}^{2} \mathrm{~s}^{-1}$. These diffusivities are slightly larger than the $1-20 \mathrm{~m}^{2} \mathrm{~s}^{-1}$ estimated by Brink (2016) using output from a primitive equation ocean model of the continental shelf and a distinct scaling that incorporated the eddy swirl velocity. In his simulations, modestly sloping isopycnals spawned a rich field of eddies owing to baroclinic instability. 


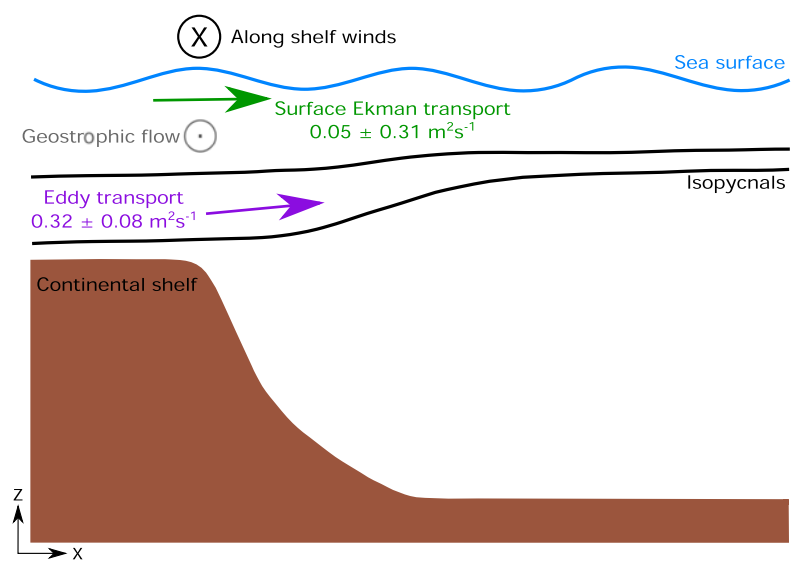

FIG. 8. Schematic of transport across the Labrador shelf break during the study period in late summer. Transport values with standard deviations are included. With both Ekman and eddy mass transport directed off the shelf, there must be one or more balancing transport processes that are unresolved in our observations. Possibilities for these processes are discussed in the text.

The magnitude, but not the sign, of the eddy transport is sensitive to a number of choices made in the scaling. Varying the choice of bounding isopycnals from ones that are evenly distributed in depth $\left(\sigma_{\theta}=27.20,27.41\right.$, $27.55,27.60$, and $27.63 \mathrm{~kg} \mathrm{~m}^{-3}$ ) to ones that are evenly distributed in isopycnal space $\left(\sigma_{\theta}=27.20,27.31,27.42\right.$, 27.52 , and $27.63 \mathrm{~kg} \mathrm{~m}^{-3}$ ) and varying the outer isopycnals by \pm 0.03 and $\pm 0.05 \mathrm{~kg} \mathrm{~m}^{-3}$ results in eddy transport ranging between 0.2 and $1 \mathrm{~m}^{2} \mathrm{~s}^{-1}$. Additional uncertainty is introduced with the selection of the baroclinic length scale [see Eq. (7)]. Regions of elevated lateral buoyancy gradient can be as narrow as $10 \mathrm{~km}$, half the $20-\mathrm{km}$ value used for the baroclinic length scale (Fig. 4), which would reduce the eddy mass transport estimate by a factor of 4 . We note that the eddy diffusivity is also likely to increase with offshore distance from the shelf break, as the baroclinic length scale widens where the flow is not focused into narrow fronts by the bathymetry. However, the diffusivity calculated in the highly baroclinic region is the appropriate one to scale the cross-slope transport by mesoscale eddies.

A schematic of the steady-state, cross-shelf mass budget for our study region in summer is proposed in Fig. 8. During July and August 2014 the average Ekman and eddy terms both transported water from the shelf to the Labrador Sea with a ratio of

$$
\frac{\mathscr{C l}_{e}}{\mathscr{C l}_{\mathrm{Ek}}}=6.2
$$

indicating that the eddy transport is greater than the Ekman transport. This contrasts the results of Thompson et al. (2014), who found the eddy transport to be about half the Ekman transport at the Antarctic shelf break in the Weddell Sea. This difference is due in part to our stronger mean eddy transport estimate, driven by a higher estimate for the diffusivity, itself a result of steeper lateral buoyancy gradients and a larger estimate of the baroclinic length scale. Such differences may result from differences in the slope of the shelf break (Stern et al. 2015). We also observe weaker Ekman transport at the Labrador shelf break than the Weddell shelf break, due to the sluggish wind stress in summer.

This mass budget is assumed to be in steady state over the 7-week study period. If the offshore Ekman and eddy transport were unbalanced over this time period, sea surface height ( $\mathrm{SSH}$ ) on the shelf would decline by roughly $5 \mathrm{~m}$ (i.e., $0.4 \mathrm{~m}^{2} \mathrm{~s}^{-1}$ from Table 3 , divided by a 300-km-wide shelf and integrated over the 7 -week study period). Given that such a decline on this time scale is unlikely, we suggest that Ekman and eddy offshore transports are balanced by processes unobserved by the glider. Thompson et al. (2014) hypothesized that on the Antarctic shelf, the cross-shelf mass budget is balanced in the bottom boundary layer (BBL). This offshore transport is expected owing to downslope export of Weddell Sea Deep Water (Foldvik et al. 2004). However, on the Labrador Shelf dense water is formed in the open ocean, and so we lack dense water export from the shelf in the BBL.

Transport in the BBL is rarely sampled and presents a particular challenge for gliders, as they run the risk of grounding if programmed to inflect too close to the sea floor. If we assume the southward geostrophic flow extends to the top of the BBL, then the bottom Ekman transport would result in additional offshore transport and is therefore not likely to close the mass budget. Other possible processes that could close the mass budget on the Labrador Shelf are: convergence of the along-shelf transport on the Labrador Shelf, onshore geostrophic flow resulting from an along-shelf pressure gradient (Stommel and Leetmaa 1972; McCabe et al. 2015), and/or deep across-shelf transport and upwelling due to the eddy- and wind-driven divergence on shelf. Denser isopycnals intersect the sea floor near the shelf break, thereby making it difficult to quantify eddy transport along deeper isopycnals (Fig. 5a). However, the isopycnal thickness gradient suggests that offshore eddy transport may persist below the layers we were able to include in our quantification.

\section{b. Freshwater transport}

Freshwater is exported offshore as a result of both Ekman and eddy transport, with the exception of the bottom two isopycnal layers used for estimating the eddy mass transport (Table 4). In these layers, the 
TABLE 4. Summary table of freshwater transport $\left(T_{\mathrm{FW}}\right)$ due to Ekman and eddy processes. The four isopycnal layers are bounded by $\sigma_{\theta}=27.20,27.41,27.55,27.60$, and $27.63 \mathrm{~kg} \mathrm{~m}^{-3}$. Rounding prevents the summation of the rows from being equal to the listed total.

\begin{tabular}{lccc}
\hline \hline & & & \multicolumn{1}{l}{$\begin{array}{c}\text { Standard } \\
\text { Transport }(\mathrm{mSv})\end{array}$} \\
\hline \multicolumn{2}{l}{ Ekman transport } \\
Cross shelf
\end{tabular}

freshwater transport is onshore because the layers are saltier than the mean $\left(S_{\text {ref }}=34.8\right.$; Table 4$)$. Uncertainty in the Ekman freshwater transport is due to the large temporal variability in the wind stress, which is propagated in our error analysis. The net freshwater export from the shelf directly to the Labrador Sea through the sum of Ekman and eddy processes is $4 \pm 6 \mathrm{mSv}(1 \mathrm{mSv}=$ $10^{3} \mathrm{~m}^{3} \mathrm{~s}^{-1}$ ), which is likely an annual maximum, as offshore Ekman transport occurs only during summer (Table 4; Fig. 7) and coincides with a seasonal salinity minimum on the Labrador Shelf (Petrie et al. 1991; Fratantoni and McCartney 2010).

The flux of freshwater crossing the Labrador Current in the study region can be compared to sources through Davis and Hudson Straits, which feed the Labrador Shelf with freshwater. Various estimates of annual mean freshwater fluxes through Davis Strait are available: 92 (Cuny et al. 2005), 105 (Curry et al. 2011), and $120 \mathrm{mSv}$ (Loder et al. 1998). The annual mean freshwater transport through Hudson Strait based on river input $(30 \mathrm{mSv})$ and through the Canadian Arctic Archipelago (CAA) through Fury and Hecla Strait $(7 \mathrm{mSv})$ sums to $37 \mathrm{mSv}$ (Straneo and Saucier 2008). Therefore, the freshwater exported to the interior Labrador Sea by Ekman and eddy processes in the study region represents $2.5 \%-3.0 \%$ of the total freshwater supplied to the Labrador Shelf from rivers and CAA flows, including Davis Strait. If we consider only the CAA export (i.e., neglecting the river runoff that is not affected by melting sea ice), these percentages increase to $3.1 \%-4.0 \%$. Finally, this result can be compared with the modeling study of Myers (2005), who found that $6 \%-8 \%$ of the $112 \mathrm{mSv}$ of simulated freshwater transport through Davis Strait penetrates into the interior Labrador Sea by all pathways on a 20 -yr time frame.

Despite that a majority of the along-shelf freshwater transport is trapped on the shelf along the western boundary of the Labrador Sea, the fraction that does get transported into the interior $(4 \pm 6 \mathrm{mSv}$; Table 4$)$ may be significant in the total freshwater budget. In the interior Labrador Sea, taken as the region deeper than $1000 \mathrm{~m}$, the imbalance between precipitation and evaporation $(P-E)$ varied from $7 \mathrm{mSv}$ over the period $1960-74$ to $9.9 \mathrm{mSv}$ from 1975-2000 (Myers et al. 2007). The strengthening of the $P-E$ imbalance by $2.9 \mathrm{mSv}$ after 1975 was associated with a well-known freshening of the subpolar North Atlantic during that period, though the relative importance of the $P-E$ change versus oceanic freshwater transport has not been robustly quantified. Additionally, the $4 \mathrm{mSv}$ of offshore freshwater transport represents $13 \%-36 \%$ of that required to restratify the halocline following wintertime convection in the Labrador Sea [11-30 mSv from April to September, from three independent studies summarized by Myers et al. (2007)]. In light of these comparisons, the freshwater supplied during the summer months could be an important, though probably not dominant, component in the freshwater budget of the interior.

\section{c. Oxygen transport}

Eddies are formed in the baroclinic region but may travel offshore before dissipating. Accordingly, they may influence biogeochemistry over the entire dissipation region where the eddy-driven tracer supply influences local tracer budgets. The eddy-driven supply of oxygen is estimated from the convergence of the $\mathrm{O}_{2}$ transport by eddies as follows:

$$
\frac{\partial T_{\mathrm{O}_{2}}}{\partial x} \approx \frac{T_{\mathrm{O}_{2}}}{\Delta x}
$$

where $T_{\mathrm{O}_{2}}$ is the transport of $\mathrm{O}_{2}$ due to Ekman and eddy processes and is assumed to go to zero over the eddy dissipation length scale $\Delta x$. This length scale of convergence is uncertain, so we present a range of supply rates for different length scales spanning from $10 \mathrm{~km}$, which is half the length of the baroclinic front, to $300 \mathrm{~km}$, the half-width of the Labrador Sea (Fig. 9). The error in the convergence of oxygen transport was found through propagating the error of the mass and tracer transports within each isopycnal layer (arising from the thickness, thickness gradient, eddy diffusivity, oxygen concentration, and oxygen concentration gradient standard deviations). 


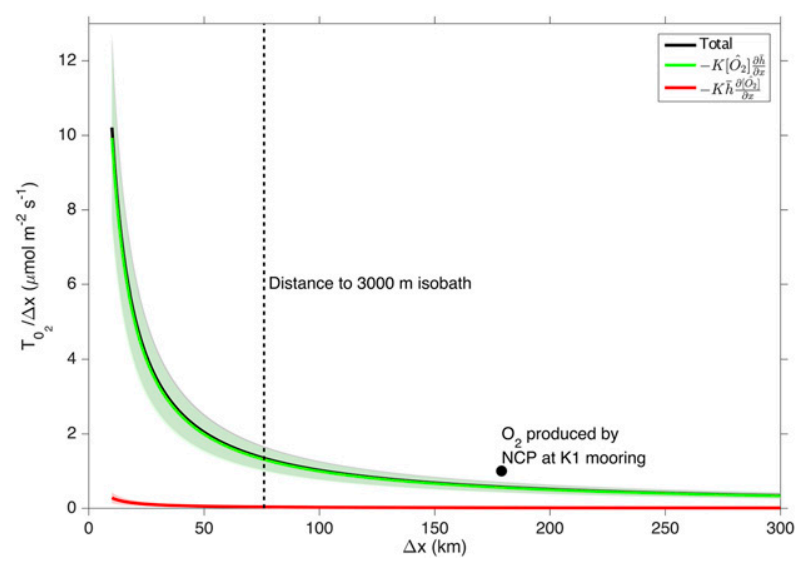

FIG. 9. Oxygen transport convergence due to parameterizations of mesoscale eddies: $-K\left[\hat{\mathrm{O}}_{2}\right] \partial \bar{h} / \partial x$ (green), $-K \bar{h} \partial\left[\hat{\mathrm{O}}_{2}\right] / \partial x$ (red), and total (black) as a function of the possible length scales over which the oxygen flux converges. The $\Delta x$ is the distance from the $500-\mathrm{m}$ isobath. The shading is the error associated with the convergence calculation. The dashed line is the distance to the $3000-\mathrm{m}$ isobath and represents the distance where the eddy kinetic energy decays to the background value (Lilly et al. 2003). The black dot represents the oxygen produced by $\mathrm{NCP}$ at the $\mathrm{K} 1$ mooring (Körtzinger et al. 2008).

Some indication of the cross-shore distance over which the eddies persist is given in Lilly et al. (2003, their Fig. 24) which shows a band of high eddy kinetic energy (EKE) near the 500-m isobath in the western Labrador Sea, presumably linked to instabilities of the shelf-break front, that decays to background EKE over a length scale of about $75 \mathrm{~km}$ to the $3000-\mathrm{m}$ isobath. We interpret the weakness of EKE beyond the 3000-m isobath as an indication that the eddies spawned at the shelf break dissipate shoreward of this isobath. In calculating the oxygen supply, we neglect the Ekman transport because it occurs almost entirely within the mixed layer where oxygen budgets are strongly forced toward equilibrium with the atmosphere.

Oxygen is often assumed to be controlled through biological net community production (NCP; i.e., the sum of the photosynthetic production of oxygen and its sink through respiration) and vertical advection and mixing (e.g., Nicholson et al. 2008). However, lateral advection can significantly contribute to a region's oxygen budget (e.g., Stramma et al. 2010). Figure 9 provides a means of evaluating the influence of the eddy-driven supply of oxygen on estimates of NCP that neglect such fluxes. Körtzinger et al. (2008) estimated that NCP in the Labrador Sea fixes $4.0 \mathrm{~mol} \mathrm{C} \mathrm{m}^{-2}$ during a 9-week bloom period observed at the $\mathrm{K} 1$ mooring in the interior Labrador Sea. Given an $\mathrm{O}_{2}$ :C stoichiometric ratio of -1.34 (Körtzinger et al. 2001) and the 9-week observation period, about $1.0 \mu \mathrm{mol} \mathrm{O} \mathrm{O}^{-2} \mathrm{~s}^{-1}$ was produced by
NCP. We compare this NCP estimate to the eddy-driven supply of oxygen of $0.6 \mu \mathrm{mol} \mathrm{O}_{2} \mathrm{~m}^{-2} \mathrm{~s}^{-1}$, using an eddy dissipation length scale equal to the distance from the 500-m isobath to the $\mathrm{K} 1$ mooring. This comparison shows that the NCP estimate is roughly double the lateral supply of oxygen due to eddy processes because the mooring is located nearly $200 \mathrm{~km}$ from the shelf break. Closer to the shelf break and/or in seasons outside the spring bloom when NCP is much lower, the eddy supply could become dominant in the oxygen budgets. Vertical mixing and entrainment must also be accounted for, particularly during active convection.

\section{Conclusions}

In summary, this study has provided detailed methods for the analysis of glider data and sheds light on exchange across the Labrador shelf break. First, this study outlines a procedure for calibrating Aanderaa oxygen optodes on gliders and correcting for slow sensor response time; further testing to validate this procedure would compare a larger number of $\mathrm{O}_{2}$ data collected along glider dives against simultaneous and collocated ship-based CTD casts with a well-calibrated oxygen sensor. With this calibrated glider data, we next characterized the hydrography of the Labrador shelf-break region, where cold, fresh, high- $\mathrm{O}_{2}$ shelf water meets warmer, saltier, lower- $\mathrm{O}_{2}$ Atlantic water. The glidersections also revealed features that had not been resolved in historical observations: first, warm and salty water with origins in the Irminger Sea persist at middepth along the Newfoundland and Labrador coasts, and, second, two cyclonic mesoscale eddies with a diameter on the order of $20 \mathrm{~km}$ with strong property anomalies to at least a depth of $1000 \mathrm{~m}$. Analysis of all sections, along with remotely sensed wind stress, revealed that Ekman and eddy processes together transported approximately $0.4 \mathrm{~m}^{2} \mathrm{~s}^{-1}$ of water offshore during the 2014 summer. This is expected to be an annual maximum, as offshore Ekman transport only occurs during summer. Notably, eddy transport is responsible for about $84 \%$ of this transport. However, uncertainties in the eddy scaling could allow for eddies to contribute as little as $43 \%$ or as much as $95 \%$ of the cross-shelf transport, with most of this uncertainty owing to the estimated baroclinic length scale. The Ekman and eddy processes are collectively responsible for moving $4 \mathrm{mSv}$ of freshwater offshore, representing only about $3 \%$ of the source freshwater from Hudson and Davis Straits during summer, and likely less than this during the other seasons. Finally, we estimated the cross-slope oxygen transport by eddy processes. Depending on the distance over which the eddy-driven oxygen transport converges, 
it may represent a substantial term in local oxygen budgets of the interior Labrador Sea. However, the eddy-driven transport convergence is likely a small supply term relative to net community production in the open Labrador Sea during the spring bloom if the eddies spawned at the shelf break converge onshore of the 3000-m isobath, as expected given the large-scale EKE field (Lilly et al. 2003).

The summertime offshore transport of water across the Labrador shelf break through Ekman and eddy processes represents a contrast to the situation found on the Weddell Sea shelf break (Thompson et al. 2014), where these processes transport water onshore in summer. The difference in the direction of transport is due to differences in the orientation of the wind stress and isopycnal thickness gradients relative to the shelf break in the Weddell and Labrador Seas. Despite these differences, cross-shelf transport has the potential to influence bottom or deep water formation in both seas. Freshwater export from the Labrador Shelf is thought to impact LSW formation by stratifying the surface waters (Manabe and Stouffer 1997; Renssen et al. 2002). On the Weddell shelf, it is speculated that heat supplied to the continental shelf from the relatively warm, middepth, circumpolar deep water (CDW) through onshore mesoscale eddy transport could contribute to the basal melting of ice shelves, and in turn may influence the production of AABW (Thompson et al. 2014; Stewart and Thompson 2015).

Our synthesis suggests that, presently, only about $3 \%$ of the freshwater entering the Labrador shelf through Hudson and Davis Straits crosses the Labrador Current as a result of Ekman and eddy processes, but nevertheless this could be an important component of the freshwater budget of the Labrador Sea. This low crossshelf connectivity was diagnosed during an observational survey timed to coincide with the seasonal pulse of freshwater on the shelf. This result is in broad agreement with a modeling study that tracked Lagrangian particles from meltwater regions to the interior Labrador Sea, which noted very limited exchange across the Labrador Current (Gillard et al. 2016). Nevertheless, the size of the cross-shelf-break freshwater transport is about half the estimate for the average Labrador Sea precipitation-minus-evaporation imbalance and therefore cannot be neglected in the freshwater budget. The fact that exchange between the shelf and open ocean is limited in this region suggests that studies aiming to understand the role of meltwater on Labrador Sea convection should accurately represent the source regions for that meltwater. Indeed, it is suggestive that modeling studies that "hose" the Labrador Sea by putting a freshwater flux over a broad region of the Labrador Sea (Renssen et al. 2002) generally have a stronger AMOC suppression than those that deploy the freshwater in its source regions and let model physics (including parameterized eddies) transport that freshwater into the interior Labrador Sea (Morrill et al. 2013).

Acknowledgments. We would like to acknowledge NSERC for funding this project through a CCAR grant to support the Ventilation, Interactions and Transports across the Labrador Sea (VITALS) program (VITALS RGPCC 433898) and through an Alexander Graham Bell Canada Graduate Scholarship (CGS M) for TH. Funding was also provided from McGill University. We also greatly appreciated the support from Blair Greenan and the crew of the CCGS Hudson in the deployment of the gliders. We also thank Stephen Punshon, for Winkler titration training; Sarah Marcil for conducting the Winkler titrations; Paul Myers for comments on a version of the manuscript; Carla Caverhill for supplying us with the satellite SST data; the crew of the fishing vessel, Estrela Dumar, that recovered the gliders; and Captain Jaime Hiscock, for help with the first glider deployment in Trinity Bay. We are also grateful to the three reviewers whose comments and suggestions significantly improved our manuscript.

\section{REFERENCES}

Aanderaa Data Instruments, 2014: TD 269 operating manual oxygen optode 4330, 4831, 4835. Aanderaa Data Instruments AS, 84 pp.

Bentamy, A., and D. C. Fillon, 2012: Gridded surface wind fields from Metop/ASCAT measurements. Int. J. Remote Sens., 33, 1729-1754, https://doi.org/10.1080/01431161.2011.600348.

Bevington, P. R., 1969: Data Reduction and Error Analysis for the Physical Sciences. McGraw-Hill, 336 pp.

Bower, A., M. Lozier, S. F. Gary, and C. W. Böning, 2009: Interior pathways of the North Atlantic meridional overturning circulation. Nature, 459, 243-247, https://doi.org/10.1038/ nature 07979.

Brink, K. H., 2016: Continental shelf baroclinic instability. Part 1: Relaxation from upwelling or downwelling. J. Phys. Oceanogr., 46, 551-568, https://doi.org/10.1175/JPO-D-15-0047.1.

Colbourne, E., B. deYoung, S. Narayanan, and J. Helbig, 1997: Comparison of hydrography and circulation on the Newfoundland Shelf during 1990-1993 with the long-term mean. Can. J. Fish. Aquat. Sci., 54, 68-80, https://doi.org/10.1139/f96-156.

Csanady, G. T., and P. Hamilton, 1988: Circulation of slopewater. Cont. Shelf Res., 8, 565-624, https://doi.org/10.1016/0278-4343 (88)90068-4.

Cuny, J., P. B. Rhines, and R. Kwok, 2005: Davis Strait volume, freshwater, and heat fluxes. Deep-Sea Res. I, 52, 519-542, https://doi.org/10.1016/j.dsr.2004.10.006.

Curry, B., C. M. Lee, and B. Petrie, 2011: Volume, freshwater, and heat fluxes through Davis Strait, 2004-05. J. Phys. Oceanogr., 41, 429-436, https://doi.org/10.1175/2010JPO4536.1.

Cushman-Roisin, B., and J.-M. Beckers, 2011: Introduction to Geophysical Dynamics: Physical and Numerical Aspects. 2nd ed. Academic Press, 875 pp. 
Dickson, R., B. Rudels, S. Dye, M. Karcher, J. Meincke, and I. Yashayaev, 2007: Current estimates of freshwater flux through Arctic and subarctic seas. Prog. Oceanogr., 73, 210-230, https://doi.org/10.1016/j.pocean.2006.12.003.

Drinkwater, K. F., 1996: Atmospheric and oceanic variability in the northwest Atlantic during the 1980s and early 1990s. J. Northwest Atl. Fish. Sci., 18, 77-97, https://doi.org/ 10.2960/J.v18.a6.

Fofonoff, N. P., S. P. Hayes, and R. C. Millard Jr., 1974: W.H.O.I./ Brown CTD microprofiler: Methods of calibration and data handling. Woods Hole Oceanographic Institution Tech. Rep. WHOI-74-89, 64 pp., https://doi.org/10.1575/1912/647.

Foldvik, A., and Coauthors, 2004: Ice shelf water overflow and bottom water formation in the southern Weddell Sea. J. Geophys. Res., 109, C02015, https://doi.org/10.1029/ 2003JC002008.

Fratantoni, P. S., and R. S. Pickart, 2007: The western North Atlantic shelfbreak current system in summer. J. Phys. Oceanogr., 37, 2509-2533, https://doi.org/10.1175/JPO3123.1.

— Labrador Current to the North Atlantic Current at the tail of the Grand Banks of Newfoundland. Deep-Sea Res. I, 57, 258-283, https://doi.org/10.1016/j.dsr.2009.11.006.

Furey, H. H., and A. S. Bower, 2009: Export pathways from the subpolar North Atlantic: DLD2 RAFOS float data report July 2003-November 2008. Woods Hole Oceanographic Institution Tech. Rep. WHOI-2009-06, 165 pp.

Gent, P. R., and J. C. McWilliams, 1990: Isopycnal mixing in ocean circulation models. J. Phys. Oceanogr., 20, 150-155, https://doi.org/10.1175/1520-0485(1990)020<0150:IMIOCM >2.0. $\mathrm{CO} ; 2$.

Gillard, L. C., X. Hu, P. G. Myers, and J. L. Bamber, 2016: Meltwater pathways from marine terminating glaciers of the Greenland ice sheet. Geophys. Res. Lett., 43, $10873-10882$, https://doi.org/10.1002/2016GL070969.

Griffies, S. M., 2004: Fundamentals of Ocean Climate Models. Princeton University Press, 496 pp.

Han, G., Z. Lu, Z. Wang, J. Helbig, N. Chen, and B. de Young, 2008: Seasonal variability of the Labrador Current and shelf circulation off Newfoundland. J. Geophys. Res., 113, C10013, https://doi.org/10.1029/2007JC004376.

IOC, SCOR, and IAPSO, 2010: The International Thermodynamic Equation of Seawater-2010: Calculation and use of thermodynamic properties. Intergovernmental Oceanographic Commission, Manuals and Guides 56, 220 pp., http://www.teos-10.org/pubs/TEOS-10_Manual.pdf.

Körtzinger, A., J. I. Hedges, and P. D. Quay, 2001: Redfield ratios revisited: Removing the biasing effect of anthropogenic $\mathrm{CO}_{2}$. Limnol. Oceanogr., 46, 964-970, https://doi.org/ 10.4319/lo.2001.46.4.0964.

- U. Send, D. W. R. Wallace, J. Karstensen, and M. DeGrandpre, 2008: Seasonal cycle of $\mathrm{O}_{2}$ and $p \mathrm{CO}_{2}$ in the central Labrador Sea: Atmospheric, biological, and physical implications. Global Biogeochem. Cycles, 22, GB1014, https:// doi.org/10.1029/2007GB003029.

Lavender, K. L., W. B. Owens, and R. E. Davis, 2005: The middepth circulation of the subpolar North Atlantic Ocean as measured by subsurface floats. Deep-Sea Res. I, 52, 767-785, https://doi.org/10.1016/j.dsr.2004.12.007.

Lazier, J. R. N., and D. G. Wright, 1993: Annual velocity variations in the Labrador Current. J. Phys. Oceanogr., 23, 659-678, https://doi.org/10.1175/1520-0485(1993)023<0659:AVVITL>2.0. $\mathrm{CO} ; 2$.
Lenn, Y.-D., and T. K. Chereskin, 2009: Observations of Ekman currents in the Southern Ocean. J. Phys. Oceanogr., 39, 768779, https://doi.org/10.1175/2008JPO3943.1.

Lilly, J. M., P. B. Rhines, F. Schott, K. Lavender, J. Lazier, U. Send, and E. D'Asaro, 2003: Observations of the Labrador Sea eddy field. Prog. Oceanogr., 59, 75-176, https://doi.org/10.1016/ j.pocean.2003.08.013.

Loder, J. W., B. Petrie, and G. Gawarkiewicz, 1998: The coastal ocean off northeastern North America: A large-scale view. The Global Coastal Ocean: Regional Studies and Syntheses, A. R. Robinson and K. H. Brink, Eds., The Sea-Ideas and Observations on Progress in the Study of Seas, Vol. 11, John Wiley, 105-133.

Manabe, S., and R. J. Stouffer, 1997: Coupled ocean-atmosphere model response to freshwater input: Comparison to Younger Dryas Event. Paleoceanography, 12, 321-336, https://doi.org/ 10.1029/96PA03932.

Mantyla, A. W., and J. L. Reid, 1983: Abyssal characteristics of the World Ocean waters. Deep-Sea Res., 30A, 805-833, https:// doi.org/10.1016/0198-0149(83)90002-X.

McCabe, R. M., B. M. Hickey, E. P. Dever, and P. MacCready, 2015: Seasonal cross-shelf flow structure, upwelling relaxation, and the alongshelf pressure gradient in the Northern California Current System. J. Phys. Oceanogr., 45, 209-227, https://doi.org/10.1175/JPO-D-14-0025.1.

McDougall, T. J., and P. M. Barker, 2011: Getting started with TEOS-10 and the Gibbs Seawater (GSW) oceanographic toolbox. SCOR/IAPSO Working Group 127 Rep., 28 pp.

McWilliams, J. C., 1985: Submesoscale, coherent vortices in the ocean. Rev. Geophys., 23, 165-182, https://doi.org/10.1029/ RG023i002p00165.

Molemaker, M. J., J. C. McWilliams, and W. K. Dewar, 2015: Submesoscale instability and generation of mesoscale anticyclones near a separation of the California Undercurrent. J. Phys. Oceanogr., 45, 613-629, https://doi.org/10.1175/JPO-D-13-0225.1.

Morrill, C., A. N. LeGrande, H. Renssen, P. Bakker, and B. L. Otto-Bliesner, 2013: Model sensitivity to North Atlantic freshwater forcing at $8.2 \mathrm{ka}$. Climate Past, 9, 955-968, https:// doi.org/10.5194/cp-9-955-2013.

Myers, P. G., 2005: Impact of freshwater from the Canadian Arctic Archipelago on Labrador Sea Water formation. Geophys. Res. Lett., 32, L06605, https://doi.org/10.1029/2004GL022082.

—, S. A. Josey, B. Wheler, and N. Kulan, 2007: Interdecadal variability in Labrador Sea precipitation minus evaporation and salinity. Prog. Oceanogr., 73, 341-357, https://doi.org/ 10.1016/j.pocean.2006.06.003.

Nicholson, D., S. Emerson, and C. C. Eriksen, 2008: Net community production in the deep euphotic zone of the subtropical North Pacific gyre from glider surveys. Limnol. Oceanogr., $\mathbf{5 3}$ 2226-2236, https://doi.org/10.4319/lo.2008.53.5_part_2.2226.

Orsi, A. H., G. C. Johnson, and J. L. Bullister, 1999: Circulation, mixing, and production of Antarctic Bottom Water. Prog. Oceanogr., 43, 55-109, https://doi.org/10.1016/S0079-6611(99)00004-X.

Palter, J. B., M. S. Lozier, and K. L. Lavender, 2008: How does Labrador Sea Water enter the Deep Western Boundary Current? J. Phys. Oceanogr., 38, 968-983, https://doi.org/ 10.1175/2007JPO3807.1.

_ I. Marinov, J. L. Sarmiento, and N. Gruber, 2013: Largescale, persistent nutrient fronts of the World Ocean: Impacts on biogeochemistry. Chemical Oceanography of Frontal Zones, I. M. Belkin, Ed., Springer, 1-38.

Petrie, B., J. W. Loder, S. Akenhead, and J. Lazier, 1991: Temperature and salinity variability on the eastern Newfoundland 
shelf: The annual harmonic. Atmos.-Ocean, 29, 14-36, https:// doi.org/10.1080/07055900.1991.9649390.

$\ldots, \ldots, \ldots$, and ——, 1992: Temperature and salinity variability on the eastern Newfoundland shelf: The residual field. Atmos.-Ocean, 30, 120-139, https://doi.org/10.1080/ 07055900.1992 .9649433$.

Pickart, R. S., D. J. Torres, and R. A. Clarke, 2002: Hydrography of the Labrador Sea during active convection. J. Phys. Oceanogr., 32, 428-457, https://doi.org/10.1175/1520-0485(2002)032<0428: HOTLSD $>2.0 . C O ; 2$.

Renssen, H., H. Goosse, and T. Fichefet, 2002: Modeling the effect of freshwater pulses on the early Holocene climate: The influence of high-frequency climate variability. Paleoceanography, 17, 1020, https://doi.org/10.1029/ 2001PA000649.

Rhines, P. B., 1982: Basic dynamics of the large-scale geostrophic circulation. Woods Hole Oceanographic Institution Tech. Rep., 47 pp.

Risien, C. M., and D. B. Chelton, 2008: A global climatology of surface wind and wind stress fields from eight years of QuikSCAT scatterometer data. J. Phys. Oceanogr., 38, 2379-2413, https://doi.org/10.1175/2008JPO3881.1.

Smith, E. H., F. M. Soule, and O. Mosby, 1937: The Marion and General Greene Expeditions to Davis Strait and Labrador Sea. U.S. Coast Guard, 259 pp.

Stern, A., L.-P. Nadeau, and D. Holland, 2015: Instability and mixing of zonal jets along an idealized continental shelf break. J. Phys. Oceanogr., 45, 2315-2338, https://doi.org/10.1175/ JPO-D-14-0213.1.

Stewart, A. L., and A. F. Thompson, 2015: Eddy-mediated transport of warm Circumpolar Deep Water across the Antarctic
Shelf Break. Geophys. Res. Lett., 42, 432-440, https://doi.org/ 10.1002/2014GL062281.

Stommel, H., and A. Leetmaa, 1972: Circulation on the continental shelf. Proc. Natl. Acad. Sci. USA, 69, 3380-3384, https://doi.org/ 10.1073/pnas.69.11.3380.

Stramma, L., G. C. Johnson, E. Firing, and S. Schmidtko, 2010: Eastern Pacific oxygen minimum zones: Supply paths and multidecadal changes. J. Geophys. Res., 115, C09011, https:// doi.org/10.1029/2009JC005976.

Straneo, F., and F. J. Saucier, 2008: The Arctic-subarctic exchange through Hudson Strait. Arctic-Subarctic Ocean Fluxes: Defining the Role of the Northern Seas in Climate, R. R. Dickson, J. Meincke, and P. Rhines, Eds., Springer, 249-261.

Thompson, A. F., K. J. Heywood, S. Schmidtko, and A. L. Stewart, 2014: Eddy transport as a key component of the Antarctic overturning circulation. Nat. Geosci., 7, 879-884, https:// doi.org/10.1038/ngeo2289.

Visbeck, M., J. Marshall, T. Haine, and M. Spall, 1997: Specification of eddy transfer coefficients in coarse-resolution ocean circulation models. J. Phys. Oceanogr., 27, 381-402, https:// doi.org/10.1175/1520-0485(1997)027<0381:SOETCI >2.0.CO;2.

Yashayaev, I., and J. W. Loder, 2016: Recurrent replenishment of Labrador Sea Water and associated decadal-scale variability. J. Geophys. Res. Oceans, 121, 8095-8114, https://doi.org/ 10.1002/2016JC012046.

—, and — 2017: Further intensification of deep convection in the Labrador Sea in 2016. Geophys. Res. Lett., 44, 1429-1438, https://doi.org/10.1002/2016GL071668.

Young, W. R., 2012: An exact thickness-weighted average formulation of the Boussinesq equations. J. Phys. Oceanogr., 42, 692-707, https://doi.org/10.1175/JPO-D-11-0102.1. 